\title{
Effects of temperature, salinity and dissolved oxygen on excystment of podocysts in the edible jellyfish Rhopilema esculentum Kishinouye, 1891
}

\author{
ZHIDE FU ${ }^{2}$, YIXUAN XING ${ }^{2}$, ZHIFENG GU ${ }^{1}$, CHUNSHENG LIU ${ }^{1}$ AND SIQING CHEN ${ }^{3}$ \\ ${ }^{1}$ State Key Laboratory of Marine Resource Utilisation in South China Sea, Ocean College, Hainan University \\ Haikou, 570 228, PR China \\ ${ }^{2}$ Hainan Academy of Ocean and Fisheries Sciences, Haikou 570 204, PR China \\ ${ }^{3}$ Yellow Sea Fisheries Research Institute, Chinese Academy of Fishery Sciences, Qingdao 266 071, PR China \\ e-mail:lcs5113@163.com
}

\begin{abstract}
The scyphozoan jellyfish Rhopilema esculentum Kishinouye, 1891 is a species occurring in the traditional fishery in China. However, the yield of this species in fishery has rapidly declined since 1980s. The podocyst is an important phase during asexual reproduction in Scyphozoa and is considered to be potentially important to the population dynamics of jellyfish. In this study, we investigated the microstructure and effects of environmental factors on the excystment of podocysts. Podocysts of greater than 8 months of age exhibited no morphological differences compared to newly formed podocysts. Following excystment, a smooth-edged hole, probably created by enzymatic digestion was observed. Excystment sharply increased when the water temperature was higher than $18^{\circ} \mathrm{C}$, suggesting that temperature ranging from approximately $13-18^{\circ} \mathrm{C}$ triggers the excystment of podocysts in $R$. esculentum. Stepwise temperature variation suggested that cooling was much more effective than warming in the induction of $R$. esculentum podocysts to excyst. The optimal salinity and dissolved oxygen (DO) conditions for excystment were observed to be 20\%o and $6 \mathrm{mg} \mathrm{O}_{2} \mathrm{l}^{-1}$ respectively. Furthermore, excystment was suppressed by both stepwise increase and decrease in salinity or DO. Though $R$. esculentum podocysts could survive extreme environmental conditions such as hypoxia and low salinity, excystment rates were markedly reduced compared to those of other bloom jellyfish species when the DO and salinity levels were returned to normal.
\end{abstract}

Keywords: Environmental factors, Excystment, Podocyst, Rhopilema esculentum

\section{Introduction}

The edible jellyfish is a popular seafood in Eastern and Southern Asia, particularly in China, where jellyfish have been commercially exploited for the past 1700 years (Morikawa, 1984; Omori and Nakano, 2001). Recently, the United States, Mexico, Australia and India have also begun to utilise available species of edible jelly fish. This has created a multi-million dollar industry, which is on the increase worldwide (Hsieh et al., 2001; Pitt and Kingsford, 2003; You et al., 2007). It has been reported that more than twelve jellyfish species, belonging to the order Rhizostomeae, were being harvested, processed and sold in international markets (TSID, 2011). In China, the edible jellyfish Rhopilema esculentum Kishinouye, 1891 is a traditional delicacy and is considered good for human health. This has resulted in exploration of the species as an important fishery resource and cultivation for commercial harvest (Dong et al., 2009; Purcell et al., 2013). It has been reported that numbers of wild caught $R$. esculentum has rapidly declined since the 1980s. Large-scale release of cultured jellyfish was done by the Chinese Government to prevent resource depletion in coastal provinces (Dong et al., 2009).

Jellyfish blooms have become more extensive and frequent worldwide over the past several decades (Mill, 2001; Kawahara et al., 2006; Uye, 2011; Brotz et al., 2012). Along the coastal areas of Eastern Asia where $R$. esculentum inhabit, other jellyfish species of little or no economic value, such as Nemopilema nomurai, Aurelia aurita and Cyanea nozakii, have formed large blooms since the late 1990s (Dong et al., 2010; Qiu, 2014). It has been hypothesised that man-made climate change is considered to be the main driving influence on jellyfish blooms as well as for the differential bloom population size between $R$. esculentum and other jellyfish species that lived in the same coastal areas (Mills, 2001; Liu and Diamond, 2005; Purcell et al., 2007; Lo et al., 2008; Dong et al., 2010). However, our understanding of the root causes of the reduction in the $R$. esculentum population remains limited. Like most scyphozoan species, the life cycle of $R$. esculentum alternates between a sexual (planktonic) medusa phase 
and an asexual (benthic) polyp phase (Ding and Chen, 1981). With respect to the population dynamics of scyphozoan medusae, the asexual (benthic) polyp phase has been considered an important determinant. Long time dormancy, as well as the tolerance to abnormal environmental conditions of podocysts of $N$. nomurai and $A$. aurita showed that their behaviour, maintaining dormancy or mass excystment, might influence medusa population sizes (Thein et al., 2012; Kawhara et al., 2013).

The podocyst that is produced beneath the pedal disc of the polyp is an encapsulated dormant stage in the life cycle of many rhizostome and semaeostome jellyfish species (Chapman, 1968; Arai, 2009). Histological examination reveals that podocysts are chitin-covered cysts which contain stores of organic compounds. This possibly results in a tolerance of the podocyst to unfavourable environmental conditions, including low temperature, hypoxia, infestation by bacteria and fungi, as well as to predatory nudibranchs (Blanquet, 1972; Black, 1981; Kawahara, 2006; Ikeda et al., 2011; Thein et al., 2012). According to present knowledge, a single polyp can produce dozens of podocysts under certain environmental conditions. When cultured artificially, a single polyp of $R$. esculentum, Chrysaora quinquecirrha and Chrysaora fuscescens formed 10 (Lu et al., 1997), 52 (Cargo and Schultz, 1967) and 53 (Widmer, 2008) podocysts, respectively within a month's time. However, the excystment rates of podocysts vary. For example, excystment rates of podocysts of $R$. esculentum were 18-69\%, according to differentstudies(Luetal., 1997; You et al., 2010). Therefore, it seems that excystment, at least for $R$. esculentum, ultimately affects the recruitment of polyps relative to the formation of podocyst.

Previous studies have shown that excystment of podocysts are affected by environmental factors such as temperature, salinity and dissolved oxygen (DO) (Arai, 2009; Han and Uye, 2010; Wang et al., 2014; Feng et al., 2015). Moreover, the key induction factors and conditions varied among different jellyfish species, such as lowering temperatures and returning to aerobic conditions from hypoxia in Chrysaora pacifica, C. nozakii and A. aurita and high temperature, low salinity and hypoxia in N. nomurai (Thein, 2012; Kawhara et al., 2013; Thein et al., 2013). Here, we hypothesised that the three environmental factors viz., temperature, salinity and DO influence the excystment of $R$. esculentum podocysts. In the present study, we investigated the ecophysiological characteristics of $R$. esculentum podocysts, and studied the effects of different environmental factors on its excystment.

\section{Materials and methods}

\section{Podocyst preparation}

Podocysts of $R$. esculentum were produced by polyps used for artificial seed production from a medusa breeding farm in Jiangsu Province, China. Mature wild $R$. esculentum medusae were caught and induced to spawn at $26^{\circ} \mathrm{C}$ during mid-August from the coastal area of Jiangsu Province. Hatched planulae were allowed to attach to opaque corrugated plates $(40 \times 35 \mathrm{~cm})$ after $28 \mathrm{~h}$. The metamorphosed polyps were fed their own unattached planulae before they developed to 8-tentacled polyps and then with fresh Artemia nauplii. Finally, the polyps were maintained in a refrigerated room $\left(6-8^{\circ} \mathrm{C}\right)$ for long term preservation. The following May ( 9 months postcollection), polyps were transferred into a $20 \mathrm{~m}^{3}$ pool and fed fresh Artemia nauplii daily to induce artificial medusa production at $20 \pm 2^{\circ} \mathrm{C}$. In addition to medusa production, abundant podocysts were also produced after the breeding season. These podocysts were then kept for 8 months (from August to March) in a $10 \mathrm{~m}^{3}$ pool, where the water temperatures mimicked those of their natural habitat, ranging from 8 to $28^{\circ} \mathrm{C}$, with a salinity of $29.5 \pm 1 \%$ and exposure to light was prevented, to the greatest extent possible. The water in the pool was replaced with filtered seawater (DO 5-6 $\mathrm{mg} \mathrm{l}^{-1}$ ) biweekly.

\section{Examination of podocysts by light and electron microscopy}

Podocysts were examined under light microscopy and scanning electron microscopy (SEM) to study podocyst microstructures at different developmental stages. Briefly, 200 podocysts ( $>8$ months of age) were maintained at $23^{\circ} \mathrm{C}$ in the dark in glass culture dishes filled with fresh seawater. Excystment was studied with the assistance of a stereo microscope (Olympus AX and Olympus SZX, Japan). For SEM, podocysts in dormancy and after excystment were fixed in 3\% glutaraldehyde prepared in 0.1 M Na-cacodylate buffer ( $\mathrm{pH} 7.2)$ for $2 \mathrm{~h}$ at room temperature. Fixed podocysts were then transferred to $1.5 \mathrm{ml}$ microcentrifuge tubes and post-fixed in $2.5 \%$ glutaraldehyde prepared in $0.1 \mathrm{M}$ cacodylate buffer $(\mathrm{pH}$ 7.2) at $4{ }^{\circ} \mathrm{C}$. Following fixation, the podocysts were washed in cacodylate buffer for $15-30 \mathrm{~min}$, then dehydrated in $50 \%$ ethanol for $3 \mathrm{~min}, 100 \%$ ethanol for $5 \mathrm{~min}, 100 \%$ acetone for $3 \mathrm{~min}$ and dried in Tetramethylsilane. The dried samples were mounted on the specimen holder with double sided adhesive tape, sputter-coated with platinum/ palladium and examined in a scanning electron microscope, (JEM-1200EX). The SEM images were transferred to a computer for image analysis. 


\section{Effects of environmental conditions on excystment}

Prior to the experiment, corrugated sheets were cut into $10 \times 5 \mathrm{~cm}$ pieces and unqualified podocysts, including dead (which showed dispersed cell mass or empty in cyst capsule under light microscope) and small ones (diameter less than $200 \mu \mathrm{m}$ ), were removed. Sheets with more podocysts (more than 100 per piece) were selected and reared in 21 glass beakers. For all environmental experiments on excystment, podocysts were stored in 2501 incubators (Jiangnan SPX). The water in the beakers was replaced every five days.

To examine the effects of environmental conditions on excystment, the cumulative excystment rates and mortality of podocysts were observed under different temperature, salinity and DO (Table 1). Numbers of podocyst excystments were counted every five days for two months. The experimental design was as follows:

Temperature: Three treatments (Treatment I used constant temperature, Treatment II used stepwise increase in temperature and Treatment III used stepwise decrease in temperature). Treatment I: Twelve sheets with more than 100 dormant podocysts in each were randomly divided into four groups and transferred directly to four temperature levels of $13,18,23$ and $28^{\circ} \mathrm{C}$. Treatment II: twelve sheets were randomly divided into four groups $\left(\mathrm{A}_{\mathrm{ti}}, \mathrm{B}_{\mathrm{ti}}, \mathrm{C}_{\mathrm{ti}}\right.$ and $\mathrm{D}_{\mathrm{ti}}$ ). The temperature of the $\mathrm{A}_{\mathrm{ti}}$ group was maintained at $13^{\circ} \mathrm{C}$.Temperature of $\mathrm{B}_{\mathrm{ti}}$ group was increased from 13 to $18^{\circ} \mathrm{C}$ at a rate of $1^{\circ} \mathrm{C}$ per day and then maintained at $18^{\circ} \mathrm{C}$. Similarly, the temperatures of $\mathrm{C}_{\mathrm{ti}}$ and $\mathrm{D}_{\mathrm{ti}}$ groups were increased from 13 to 23 and $28^{\circ} \mathrm{C}$ respectively. Treatment III: twelve sheets were randomly divided into four groups $\left(\mathrm{A}_{\mathrm{td}}, \mathrm{B}_{\mathrm{td}}, \mathrm{C}_{\mathrm{td}}\right.$ and $\left.\mathrm{D}_{\mathrm{td}}\right)$. The temperature of $\mathrm{A}_{\mathrm{td}}$ was maintained at $28^{\circ} \mathrm{C}$. The temperature of $B_{\text {td }}$ group was decreased from 28 to $23^{\circ} \mathrm{C}$ at a rate of $1^{\circ} \mathrm{C}$ per day and then maintained at $23^{\circ} \mathrm{C}$. Similarly, the temperatures of the $\mathrm{C}_{\mathrm{td}}$ and $\mathrm{D}_{\mathrm{td}}$ groups were decreased from 28 to 18 and $13^{\circ} \mathrm{C}$, respectively, at a rate of $1^{\circ} \mathrm{C}$ per day.

Salinity: For the salinity experiments, the environmental salinity concentrations were achieved by diluting seawater to calculated percentages in purified freshwater. Three separate conditions were assessed. In treatment I, podocysts were transferred directly to different salinity levels, either $15,20,25$ or $30 \%$. In treatment II, the salinity of four groups were all increased stepwise from 15 to 20,25 and $30 \%$ o by gradually elevating the salinity $1 \%$ o per day; In treatment III, the salinity of four groups were all decreased from 30 to 25,20 and $15 \%$ by gradually lowering the salinity $1 \%$ o per day.

Dissolved oxygen: DO experiments were conducted in 31 enclosed conical flasks. For the hypoxic group, the DO concentration was controlled by bubbling $99.9 \%$ nitrogen through the water. For the oxygen-enriched groups, DO concentration was adjusted by bubbling of $95 \%$ oxygen through the water. DO concentrations in each flask were monitored daily to verify the stability of the experimental conditions, using HQ30d multi-parameter meter $(\mathrm{HACH}$, Beijing). Moreover, in order to maintain DO stability while monitoring the excystments and dead podocysts, podocysts and the experimental seawater were quickly transferred into a petridish, checked with an inverted microscope (Nikon, 80i), and then returned to the flask. In the DO experiments, three treatments were assessed. In treatment I, podocysts were transferred directly to DO levels of 1, 3, 6 and $9 \mathrm{mg} \mathrm{O}_{2} \mathrm{l}^{-1}$. In treatment II, the DO of four groups were all increased stepwise from $1 \mathrm{mg} \mathrm{O}_{2} \mathrm{l}^{-1}$ to $1,3,6$ and $9 \mathrm{mg} \mathrm{O}_{2} \mathrm{l}^{-1}$, respectively, at the rate of 0.4 , 0.6 and $0.6 \mathrm{mg} \mathrm{O}_{2} \mathrm{1}^{-1}$ per day. In treatment III, the DO of four groups were decreased stepwise from $9 \mathrm{mg} \mathrm{O}_{2} \mathrm{l}^{-1}$ to 6,3 and $1 \mathrm{mg} \mathrm{O}_{2} 1^{-1}$, respectively, at the rate of $0.6,0.6$ and $0.4 \mathrm{mg} \mathrm{O}_{2} \mathrm{l}^{-1}$ per day.

Table 1. Experimental conditions to examine the effects of temperature, dissolved oxygen (DO) and salinity on the podocyst excystment of R. esculentum.

\begin{tabular}{llll}
\hline Environmental factor tested & \multicolumn{3}{c}{ Experimental conditions } \\
\cline { 2 - 4 } Temperature & Temperature $\left({ }^{\circ} \mathrm{C}\right)$ & DO $\left(\mathrm{mg} \mathrm{l}^{-1}\right)$ & Salinity \\
$\quad$ Different temperature levels & $13,18,23,28 \pm 0.5$ & $5-6$ & 30 \\
Stepwise temperature increase & 13 to 18,23 or 28 & $5-6$ & 30 \\
Stepwise temperature decrease & 28 to 23,18 or 13 & $5-6$ & 30 \\
\hline DO & $23 \pm 0.5$ & $1,3,6,9 \pm 0.4$ & 30 \\
Different DO levels & $23 \pm 0.5$ & 1 to 3,6, or 9 & 30 \\
Stepwise DO increase & $23 \pm 0.5$ & 9 to 6,3, or 1 & 30 \\
Stepwise DO decrease & & \\
Salinity & $23 \pm 0.5$ & $5-6$ & $15,20,25,30 \pm 1$ \\
Different salinity levels & $23 \pm 0.5$ & $5-6$ & 15 to 20,25 or 30 \\
Stepwise salinity increase & $23 \pm 0.5$ & $5-6$ & 30 to 25,20 or 15 \\
Stepwise salinity decrease &
\end{tabular}




\section{Statistical analysis}

Cumulative excystment and mortality rates of podocysts in different groups were calculated as the average rates in three replicates. Statistical analysis $(p<0.05)$ were carried out using one-way ANOVA (SPSS 15.0 software).

\section{Results}

Podocyst morphology and excystment

Podocysts of $R$. esculentum were produced beneath the pedal disc of polyps, having a diameter of about 124-400 $\mu \mathrm{m}$ (average $278 \mu \mathrm{m}$ ) in our experiment (Fig. 1a). As for podocysts produced by a same polyp, the diameters of newly formed podocysts were longer than those that were previously formed due to the growth of the polyps' bodies. Newly formed podocysts contained a milky white cell mass and soft yellowish cyst capsule (Fig. 1a). Moreover, podocysts appeared as dome-like capsules with smooth roof and roughly concave base (Fig. 2a, b). A clear space was also observed between the capsule and cell mass (Fig. 2b).

When spontaneous excystment occurred under laboratory conditions, increased cell mass was first observed under light microscope, the evidence of which was a darkened centre of podocyst, relative to the surrounding area (Fig. 1b). Thereafter, the cell mass extruded through an opening at the roof of the capsule (Fig. 2c) and developed into a four-tentacle polyp (Fig. 1c). For podocysts aged 8-9 months, the duration

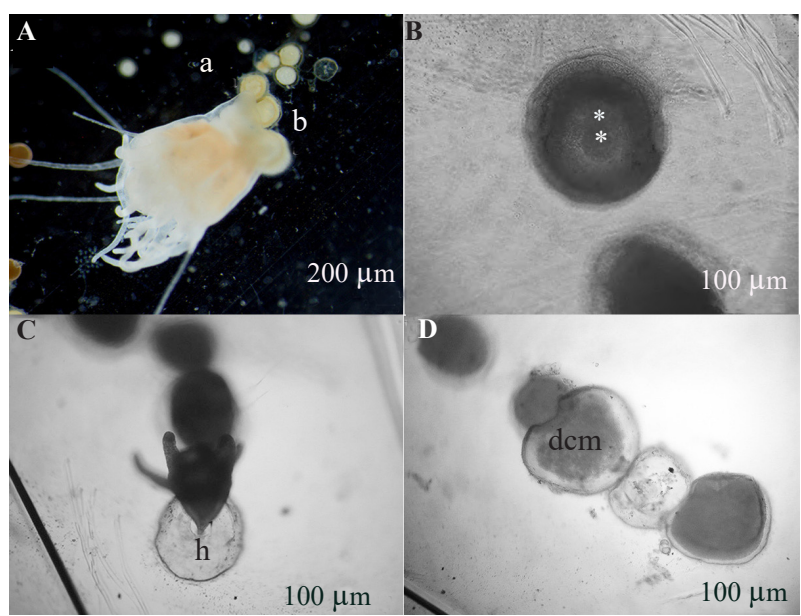

Fig. 1. External view of polyp and podocyst of R. esculentum under light microscopy. (A) Lateral view of podocyst formed by a polyp $(\mathrm{Bar}=200 \mu \mathrm{m})$. (B) Top view of excystment at early stage (Bar=100 $\mu \mathrm{m})$. (C) Lateral view of a new polyp by excystment (Bar=100 $\mu \mathrm{m})$. (D) Top view of dead podocyst $(\mathrm{Bar}=100 \mu \mathrm{m})$. a - forming podocyst; $\mathrm{b}$ - Newly formed pedal disc; * Raised cell mass; h - Hole; dcm - Dispersed cell mass. from cell mass increase to four-tencle polyp was $30-42 \mathrm{~h}$ at $23^{\circ} \mathrm{C}$.

In the roof of excysted podocyst, a hole with smooth edge, which seemed to be enzymatically dissolved, was observed (Fig. 1c and Fig. 2d). This feature allowed for the differentiation of living podocysts from those that were dormant or dead (Fig. 1d).

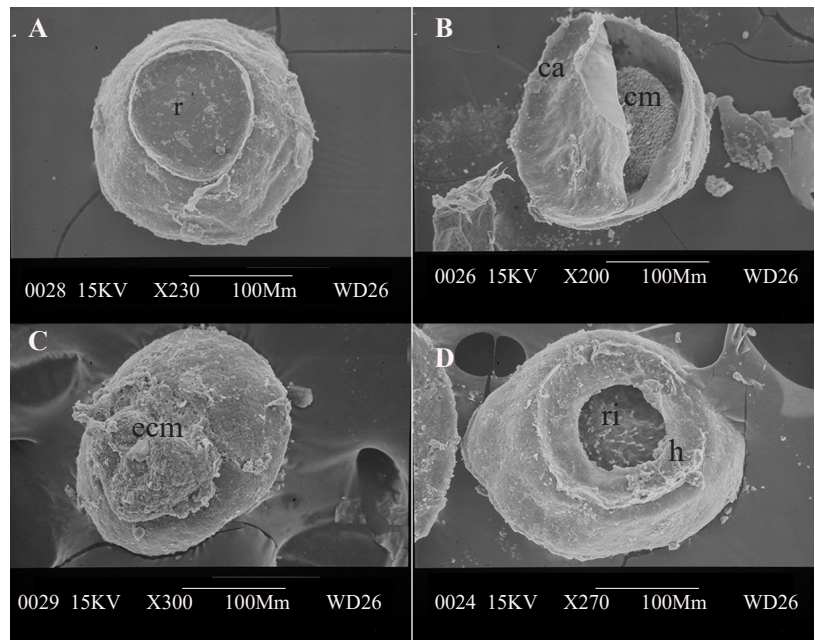

Fig. 2. External view of podocyst of R. esculentum under electron microscopy. (A) Top view of podocyst. (B) Bottom view of internal morphology of cell mass. (C) Top view of excystment. (D) Top view of cyst capsule of excystment. ca - Cyst capsule; cm - Mass of cyst cells; ecm - Extruding cell mass; $r$ - Roof; ri - Rivet; h - Hole. Bar $=100 \mu \mathrm{m}$.

\section{Effect of temperature on excystment}

Temperature variations had a pronounced effect on excystment of R. esculentum podocysts. After two months, the cumulative excystment reached 40,46 and $45 \%$ at 18 , 23 and $28^{\circ} \mathrm{C}$, respectively. By comparison, the cumulative excystment was only $5 \%$ at $13^{\circ} \mathrm{C}$ (Fig. $3 \mathrm{~A}$ ). There were significant differences in cumulative excystment rates at $13^{\circ} \mathrm{C}$ compared with the higher temperatures tested $(p<0.05)$. Moreover, the cumulative excystment rates at $18^{\circ} \mathrm{C}$ were significantly lower than those observed at 23 and $28^{\circ} \mathrm{C}$ at days $5-35$ of the experiment $(\mathrm{p}<0.05)$ (Fig. $\left.3 \mathrm{~A}\right)$ (cumulative excystment percentages indicated between vertical dashed lines). However, the differences disappeared when the induction of excystment was carried out for longer than 40 days at the three elevated temperatures tested $(\mathrm{p}>0.05)$. When podocysts were transferred from 13 to 18,23 or $28^{\circ} \mathrm{C}$, the cumulative excystment rates were 41,44 and $46 \%$, respectively and no significant difference was observed among the constant temperature groups (Fig. 3b). However, the cumulative excystment rates reached 57 and $54 \%$ when podocysts were transferred from $28^{\circ} \mathrm{C}$ to 23 and 18 respectively, 


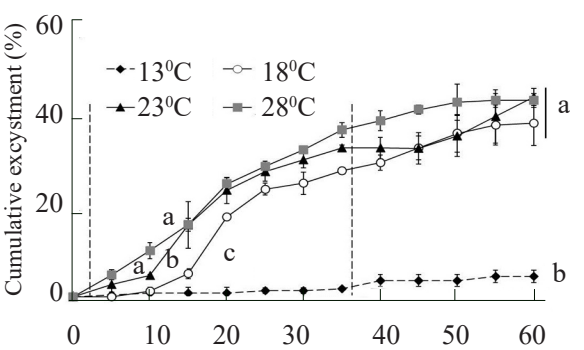

(a)

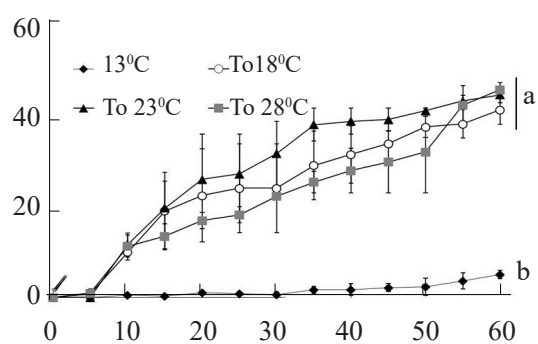

(b)

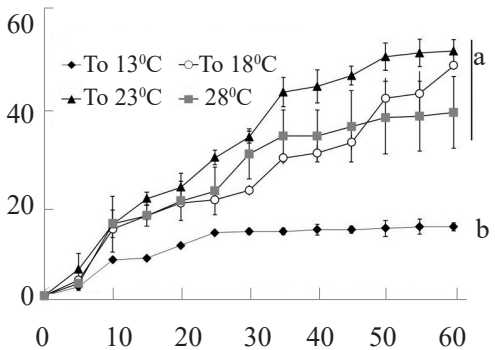

(c)

Days

Fig. 3. Cumulative excystment percentages of podocysts of R. esculentum in different temperature treatments. (a) At constant temperature of $13,18,23$ and $28^{\circ} \mathrm{C}$, (b) Stepwise increase in temperature from $13^{\circ} \mathrm{C}$ to 18,23 and $28^{\circ} \mathrm{C}$, (c) Stepwise decrease in temperature from 28 to 23,18 and $13^{\circ} \mathrm{C}$. Vertical dashed lines in plot (a) shows the differences of cumulative excystment comparing 23 and $28^{\circ} \mathrm{C}$ with $18^{\circ} \mathrm{C}$. Different letters beside the line indicate significant differences among treatments $(\mathrm{p}<0.05)$.

exhibiting substantially higher excystment rates when compared with the constant temperature treatments and stepwise temperature increase conditions (Fig. 3c). These results clearly indicated that cooling induced excystment of $R$. esculentum much more effectively than constant or increasing temperature.

\section{Effect of salinity on excystment}

Salinity was also observed to have an effect on the excystment of $R$. esculentum. The highest excystment rates were $54.98 \%$ at $20 \%$ salinity, followed by 15,25 and $30 \%$ (Fig. 4a). Variation of salinity, however, did not benefit excystment. The excystment rates of all stepwise salinity increases or decreases (except one treatment in which salinity increased from 15 to 30 ) were substantially reduced in comparison to constant conditions. To be precise, the cumulative excystment rates were 28, 36 and $46 \%$, respectively, when podocysts were transferred from 15 to 20,25 and $30 \%$ (Fig. 4b). Similarly, the cumulative excystment rates were 30,44 and $39 \%$, respectively, when podocysts were transferred from 30 to 25,20 and $15 \%$ o (Fig. 4c).

\section{Effect of DO on excystment}

The excystment rate of podocysts were significantly different among the four DO treatments tested (Fig. 5a). The highest excystment rate observed was at a DO of $6 \mathrm{mg} \mathrm{O}_{2} \mathrm{l}^{-1}(52 \%)$, followed by 3 and $9 \mathrm{mg} \mathrm{O}_{2} \mathrm{l}^{-1}$ (31 and $30 \%$, respectively) and $1 \mathrm{mg} \mathrm{O}_{2} \mathrm{l}^{-1}(17 \%)$. Significant differences were found between DO of $6 \mathrm{mg} \mathrm{O}_{2} \mathrm{1}^{-1}$ versus DO of 3, 9 and $1 \mathrm{mg} \mathrm{O}_{2} \mathrm{l}^{-1}(\mathrm{p}<0.05)$. When podocysts were transferred from $1 \mathrm{mg} \mathrm{O}_{2} \mathrm{l}^{-1}$ to 3,6 and $9 \mathrm{mg} \mathrm{O}_{2} 1^{-1}$ in a stepwise manner, the rates of excystment were all lower than those observed under constant DO conditions (Fig. 5b). A similar result was observed when podocysts were transferred from $9 \mathrm{mg} \mathrm{O}_{2} \mathrm{1}^{-1}$ to lower DO conditions. The only exception observed was when decreasing DO from 9 to $1 \mathrm{mg} \mathrm{O}_{2} \mathrm{l}^{-1}$ (21\%) (Fig. 5c).

\section{Discussion}

\section{Morphological features of podocysts}

The podocyst is an encapsulated, asexual stage in the life cycle of many rhizostome and semaeostome jellyfish species (Chapman, 1968; Arai, 2009). In our

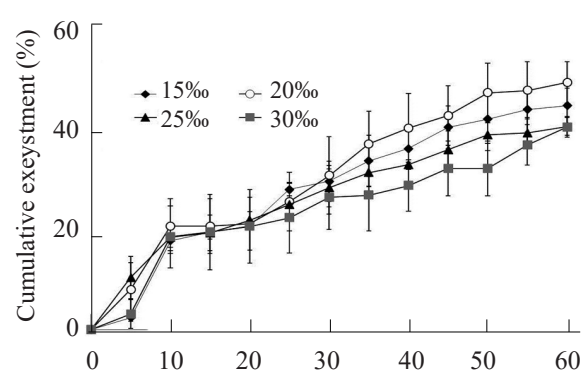

(a)

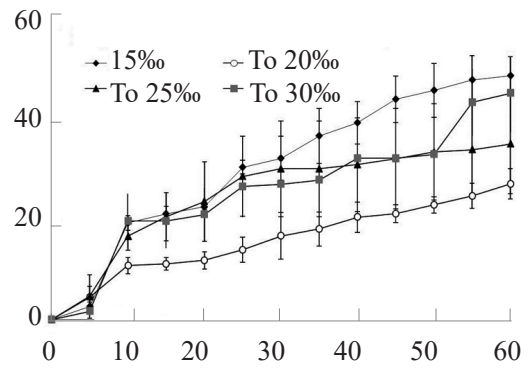

(b)

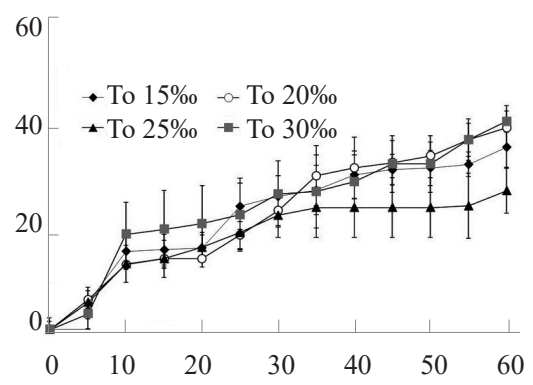

(c)

Days

Fig. 4. Cumulative excystment percentages of podocysts of $R$. esculentum in different salinity treatments. (a) At constant salinity of 15 , 20,25 and 30\%, (b) Stepwise increase in salinity from 15 to 20, 25 and 30\%o, (c) Stepwise decrease in salinity from 30 to $28,23,18$ and $15 \%$. 


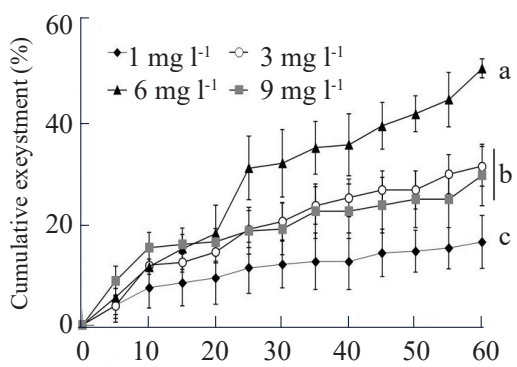

(a)

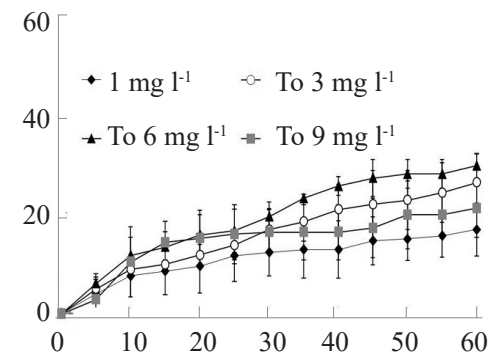

(b)

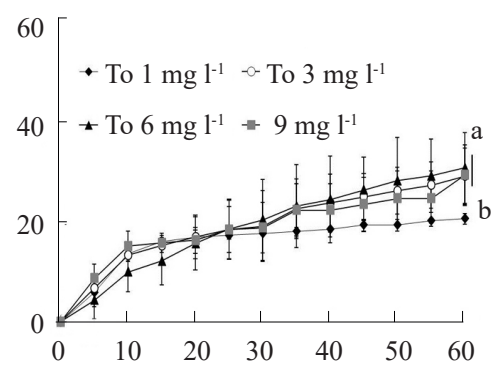

(c)

Fig. 5. Cumulative excystment percentages of podocysts of $R$. esculentum in different dissolved oxygen (DO) treatments. (a) At constant $\mathrm{DO}$ of 1,3, 6 and $9 \mathrm{mg} \mathrm{O}_{2} 1^{-1}$, (b) Stepwise increase in DO from 1 to 3, 6 and $9 \mathrm{mg} \mathrm{O}_{2} 1^{-1}$, (c) Stepwise decrease in DO from 9 to 6,3 and $1 \mathrm{mg} \mathrm{O}_{2} 1^{-1}$. Different letters beside the line indicate significant differences among treatments $(\mathrm{p}<0.05)$.

experiment, the podocysts of $R$. esculentum were the only form of asexual reproduction by polyps observed, which was consistent with observations reported by others in Rhopilema nomadica, Lychnorhiza lucerna, N. nomurai, Stomolophus meleagris and C. pacifica (Calder 1982; Kawahara et al., 2006; You et al., 2007; Schiariti et al., 2008; Thein et al., 2013). For most jellyfish species, including $R$. esculentum, podocyst formation increased under favourable environmental conditions for polyps, such as increased temperature and abundant food supplies (Lu et al., 1997; Thein et al., 2013; Feng et al., 2015). Following formation of podocysts, the jellyfish became tolerant of long-term, severe changes in the environment, such as hypoxia, low salinity and colonisation by bacteria and fungi (Blanquet, 1972; Thein et al., 2012; Kawahara et al., 2013). Similarly, in our experiment, differences among flattened cell masses could be clearly observed using light microscopy and SEM through the thin transparent capsule of $R$. esculentum podocysts that had been dormant for 8-10 months. However, we were unable to observe any obvious differences in newly formed podocysts. It has been reported that the maximum longevities of podocysts in A. aurita and $N$. nomurai were 3 and 6 years, respectively (Thein et al., 2012; Kawahara et al., 2013). These results suggest that encapsulated podocysts are capable of living much longer than other life stages of jellyfish species.

In our observation of spontaneous excystment, the cell mass of podocysts increased before the capsule ruptured. Following excystment, a hole with smooth edges in the middle of the capsule wall was observed, indicating that a mild force, such as enzymatic degradation, as opposed to a strong and sudden force, perforated the capsule. These observations were inconsistent with those of Ikeda et al. (2011), who suggested that tear strength and enzymes contributed to the rupture of inner and outer layers of the capsule, respectively. According to our observations, we inferred that the process probably transmitted a signal inducing enzyme to degrade the capsule during the early stages of excystment.

\section{Environmental factors and excystment of podocyst}

There were strong relationships observed between excystment of jellyfish and environmental factors, the key inducing factors varying among different jellyfish species (Thein, 2012; Kawhara et al., 2013; Thein et al., 2013). In our examination of excystment at different temperatures, the excystment rate was much lower at $13^{\circ} \mathrm{C}$ (only $4.77 \%$ ) than higher temperatures tested over a two months period, suggesting that there was a critical temperature $\left(13-18^{\circ} \mathrm{C}\right)$ for the induction of excystment of $R$. esculentum. This is consistent with the finding of Lu et al. (1997), who reported that podocysts did not excyst below $10^{\circ} \mathrm{C}$. Moreover, the cumulative rate of excystment did not remarkably increase when temperatures increased gradually over a period of $\geq 40$ days, suggesting that the excystment potential of dormant podocysts remained the same at excystment-triggering or higher temperatures. Temperature-trigger mechanism has been reported in other life stages such as polyp strobilation of $A$. aurita and R. esculentum (Dong et al., 2009; Fuchs et al., 2014).

The excystment rates were significantly higher (an increase of $12-13 \%$ ) under cooling conditions than in warming conditions, suggesting that autumn is the major excystment season for podocysts in $R$. esculentum. Similar findings were also reported in $C$. pacifica, $C$. nozakii and A. aurita (Thein et al., 2012; Thein et al., 2013). However, warming was observed as a trigger for excystment in other jellyfish species, such as $C$. quinquecirrha in the Chesapeake Bay and N. nomurai in East Asian marginal seas (Cargo and Schultz, 1967; Cargo and Rabenold, 1980; Kawahara et al., 2013).

Salinity has been implicated as a key factor in jellyfish dynamics (Willcox, 2006). In N. nomurai, low salinities 
(8-24) benefited excystment (Kawahara et al., 2013). In our experiment, the optimal salinity for excystment in $R$. esculentum was $20 \%$; resulting in an excystment rate of $54.98 \%$. However, no significant differences were found among the 15-30\% groups. These results indicated that salinity was not a key factor in the excystment stage of $R$. esculentum. Our study has shown that salinity fluctuation (increase or decrease) reduced the excystment of $R$. esculentum, suggesting fluctuation of supplemental freshwater affected the excystment of podocysts in the natural marine environment, as well as jellyfish population recruitment.

The excystment promoting effect of hypoxia has been observed in many jellyfish species (Thein et al., 2013). For example, excystment in $N$. nomurai increased significantly when subjected to hypoxic conditions $(1.0 \mathrm{mg}$ $\left.\mathrm{O}_{2} 1^{-1}\right)$. This phenomenon was also observed in A. aurita (Thein et al., 2012). However, for R. esculentum, which has the same geographical distribution in the coastal region of East Asia, hypoxia markedly reduced excystment in comparison to normal DO concentration. Furthermore, it is perplexing that the excystment of podocysts was induced at higher DO $\left(9 \mathrm{mg} \mathrm{O}_{2} \mathrm{l}^{-1}\right)$, although it appears to be decreased in comparison to those under normal DO conditions.

In conclusion, though the podocysts of $R$. esculentum are capable of survival in extreme environmental conditions, such as hypoxic $\left(1 \mathrm{mg} \mathrm{O}_{2} \mathrm{l}^{-1}\right)$ and low salinity (15), the excystment rates were lower when transferred to normal environmental conditions in comparison to those continually residing in a normal and constant marine environment. In contrast, other blooming jellyfish species, such as $N$. nomurai and $A$. aurita, exhibited significant increases in excystment when transferred form hypoxic to well-oxygenated seawater (Thein et al., 2012; Kawahara et al., 2013). These phenomena suggest that the podocysts of $R$. esculentum possess less adaptation mechanisms compared to other jellyfish species, which might be one of the important causes for its population decrease.

In artificial breeding of $R$. esculentum, the quantity of polyps is the most important factor that affects seed production. Excystment induction is considered to be an important method for recruitment of polyp population. However, this technique has not been established yet. On the basis of already available information (Guo, 1990; Lu et al., 1997; You et al., 2007; Liu et al., 2015) and the formation and excystment patterns of podocysts under various environmental conditions examined in this study, there are several methods that can be used to enhance polyp recruitment by excystment. Firstly, elevated temperature (but not warmer than $30^{\circ} \mathrm{C}$ ), appropriate salinity (16-26\%) and enough food supplementation benefit podocyst formation at the early polyp stage. Second, rearing podocysts under reduced temperature conditions $\left(\leq 13^{\circ} \mathrm{C}\right)$ would aid in long-term preservation. Third, a gradual temperature reduction, from 28 to $23^{\circ} \mathrm{C}$, at a rate of $1^{\circ} \mathrm{C}$ per day can efficiently induce excystment. Finally, maintenance of constant salinity and DO levels is important for increased excystment efficiency.

\section{Acknowledgements}

This research was supported by the National Key Research and Development Program of China (No. 2018YFD0900704), the Marine Economy Innovation and Development Demonstration Project of Haikou (No. HHCL201817) and the Key Research and Development Project of Hainan Province (No. ZDYF2019153).

\section{References}

Arai, M. N. 2009. The potential importance of podocysts to the formation of scyphozoan blooms: a review. Hydrobiologia, 616: 241-246.

Black, R. E. 1981. Metabolism and ultrastructure of dormant podocysts of Chrysaora quinquecirrha (Scyphozoa). J. Exp. Zool., 218: 175-182. https://doi.org/10.1002/ jez. 1402180210 .

Blanquet, R. S. 1972. Structural and chemical aspects of the podocyst cuticle of the scyphozoan medusa, Chrysaora quinquecirrha. Biol. Bull., 142: 1-10.

Brotz, L., Cheung, W. W. L., Kleisner, K., Pakhomov, E. and Pauly, D. 2012. Increasing jellyfish populations: trends in Large Marine Ecosystems. Hydrobiologia, 690: 3-20.

Calder, D. R. 1982. Life history of the cannonball jellyfish, Stomolophus meleagris L. Agassiz, 1860 (Scyphozoa, Rhizostomida). Biol. Bull., 162: 149-162.

Cargo, D. G. and Rabenold, G. E. 1980. Observations on the asexual reproductive activities of the sessile stages of the sea nettle Chrysaora quinquecirrha (Scyphozoa). Estuaries, 3: 20- 27.

Cargo, D. G. and Schultz, L. P. 1967. Further observations on the biology of the sea nettle and jellyfishes in Chesapeake Bay. Chesapeake Sci., 8: 209- 220.

Chapman, D. M. 1968. Structure, histochemistry and formation of the podocyst and cuticle of Aurelia aurita. J. Mar. Biol. Ass. UK., 48: 187-208. DOI: https://doi.org/10.1017/ S0025315400032537. 
Ding, G. W. and Chen, J. K. 1981. The life history of Rhopilema esculentum Kishinouye. J. Fish. China, 5: 93-104 (in Chinese).

Dong, J., Jiang, L. X., Tan, K. F., Liu, H. Y., Purcell, J. E., Li, P. J. and Ye, C. C. 2009. Stock enhancement of the edible jellyfish (Rhopilema esculentum Kishinouye) in Liaodong Bay, China: a review. Hydrobiologia, 616: 113-118.

Dong, Z., Liu, D. and Keesing, J. K. 2010. Jellyfish blooms in China: dominant species, causes and consequences. Mar. Pollut Bull., 60: 954-963. DOI:10.1016/j.marpolbul.2010.04.022.

Feng, S., Zhang, G. T., Sun, S., Zhang, F., Wang, S. W. and Liu, M. T. 2015. Effects of temperature regime and food supply on asexual reproduction in Cyanea nozakii and Nemopilema nomurai. Hydrobiologia, 754: 201-214.

Fuchs, B., Wang, W., Graspeuntner, S., Li, Y., Insua, S., Herbst, E. M., Dieksen, P., Bohm, A., Hemmrich, G., Sommer, F., Domazet-Loso, T., Klostermeier, U. C., Anton-Erxleben, F., Rosenstiel, P., Bosch, T. C. G. and Khalturin, K. 2014. Regulation of polyp-to-jellyfish transition in Aurelia aurita. Curr. Biol., 24: 263-273.

Guo, P. 1990. Effect of nutritional condition on the formation and germination of the podocyst of scyphistomae of Rhopilema esculentum Kishinouye. J. Fish. China, 3: 206-211 (in Chinese).

Han, C. H. and Uye, S. I. 2010. Combined effects of food supply and temperature on asexual reproduction and somatic growth of polyps of the common jellyfish Aurelia aurita Plankton Benthos Res., 5: 98-105.

Hsieh, Y. H. P., Leong, F. M. and Barnes, K. W. 2001. Jellyfish as food. Hydrobiologia, 451: 11-17.

Ikeda, H., Ohtsu, K. and Uye, S. I. 2011. Fine structure, histochemistry and morphogenesis during excystment of the podocysts of the giant jellyfish Nemopilema nomurai (Scyphozoa, Rhizostomeae). Biol. Bull., 221: 248-260. DOI:10.1086/BBLv221n3p248.

Kawahara, M., Ohtsu, K. and Uye, S. I. 2013. Bloom or non-bloom in the giant jellyfish Nemopilema nomurai (Scyphozoa: Rhizostomeae): roles of dormant podocysts. J. Plankton Res., 35: 213-217. https://doi.org/10.1093/ plankt/fbs074.

Kawahara, M. 2006. Unusual population explosion of the giant jellyfish Nemopilema nomurai (Scyphozoa: Rhizostomeae) in East Asian waters. Mar. Ecol. Prog. Ser., 307: 161-173.

Liu, C. S., Zhuang, Z. M., Chen, S. Q., Yan, J. P., Liu, C. L. and Sun, J. M. 2015. A large-scale breeding experiment and observations on development of Cyanea nozakii (Scyphozoa, Cyaneidae) from fertilised eggs to larval medusae. Hydrobiologia, 754: 113-123.
Liu, J. and Diamond, J. 2005. China's environment in a globalising world. Nature, 435: 1179-1186.

Lo, W. T., Purcell, J. E., Hung, J. J., Su, H. M. and Hsu, P. K. 2008. Enhancement of jellyfish (Aurelia aurita) populations by extensive aquaculture rafts in a coastal lagoon in Taiwan. ICES J. Mar. Sci., 65: 453-461.

Lu, N., Shuang J. and Chen, J. K. 1997. Effect of temperature, salinity and light on the podocyst generation of Rhopilema esculentum Kishinouye. Fish. Sci., 1: 3-8 (in Chinese).

Mills, C. E. 2001. Jellyfish blooms: are populations increasing globally in response to changing ocean conditions? Hydrobiologia, 451: 55-68.

Morikawa, T. 1984. Jellyfish. FAO INFOFISH Marketing Digest, 1: 37-39.

Omori, M. and Nakano, E. 2001. Jellyfish fisheries in south-east Asia. Hydrobiologia, 451: 19-26.

Pitt, K. A. and Kingsford, M. J. 2003. Temporal and spatial variation in recruitment and growth of medusae of the jellyfish, Catostylus mosaicus (Scyphozoa: Rhizostomeae). Mar. Freshw. Res., 54: 117-125.

Purcell, J. E., Baxter, E. J. and Fuentes, V. 2013. Jellyfish as products and problems for aquaculture. In: Allan, G. and Burnell, G. (Eds.), Advances in aquaculture hatchery technology. Woodhead Publishing, Cambridge, UK, p. $404-430$.

Purcell, J. E., Uye, S. and Lo, W. T. 2007. Anthropogenic causes of jellyfish blooms and their direct consequences for humans: a review. Mar. Ecol. Prog. Ser., 350: 153-174.

Qiu, J. 2014. Coastal havoc boosts jellies. Nature, 514: 545

Schiariti, A., Kawahara, M., Uye, S. and Mianzan, H. W. 2008. Life cycle of the jellyfish Lychnorhiza lucerna (Scyphozoa: Rhizostomeae). Mar. Biol., 156: 1-12.

Thein, H., Ikeda, H. and Uye, S. 2013. Ecophysiological characteristics of podocysts in Chrysaora pacifica (Goette) and Cyanea nozakii Kishinouye (Cnidaria: Scyphozoa: Semaeostomeae): Effects of environmental factors on their production, dormancy and excystment. J. Exp. Mar. Biol. Ecol., 446: 151-158.

Thein, H., Ikeda, H. and Uye, S. 2012. The potential role of podocysts in perpetuation of the common jellyfish Aurelia aurita s1 (Cnidaria: Scyphozoa) in anthropogenically perturbed coastal waters. Hydrobiologia, 690: 157-167.

TSID 2011. Trade-Seafood Industry Directory http://www.tradeseafood.com/species/ jelly-fish.htm (Accessed 01 July 2011).

Uye, S. 2011. Human forcing of the copepod-fish-jellyfish triangular trophic relationship. Hydrobiologia, 666: 71- 83

You, K., Ma, C., Gao, H., Li, F., Zhang, M., Qiu, Y. and Wang B. 2007. Research on the jellyfish (Rhopilema 
esculentum Kishinouye) and associated aquaculture techniques in China: current status. Aquac. Int., 15:479-488.

You, K., Ma, C., Wang, S., Gao, T., Li, J. and Wang, X. 2010. Effects of aeration and feeding on podocyst germination of jellyfish, Rhopolema esculentum Kishinouye. J. Fish. Sci. China, 17(6): 1352-1357 (in Chinese with English Abstract).
Widmer, C. L. 2008. Life cycle of Chrysaora fuscescens (Cnidaria: Scyphozoa) and a key to sympatric ephyrae. Pac. Sci., 62(1): 71-82.

Willcox, S. T. 2006. Ecology of moon jellyfish Aurelia sp. in southern Tasmania in relation to Atlantic salmon farming. $\mathrm{Ph}$. D. Thesis, School of Aquaculture, University of Tasmania, Tasmania. 